\title{
Erratum to: Sulla negazione nel Tristano e Isotta di Thomas tra grammatica e retorica
}

\section{Francesca Gambino ${ }^{1}$}

\section{Erratum to: Neophilologus DOI 10.1007/s11061-015-9441-9}

Unfortunately, the reference Thomas (2014) has been erroneously deleted from the original version of the article and is provided in this Erratum.

All citations of the Thomas' Tristan poem come from the edition Thomas (2014). In F. Gambino (Ed. and Trans.). Tristano e Isotta di Thomas. Modena: Mucchi.

Tutte le citazioni del Tristan di Thomas sono tratte dall'edizione Thomas (2014). In F. Gambino (Ed. and Trans.). Tristano e Isotta di Thomas. Modena: Mucchi.

The online version of the original article can be found under doi:10.1007/s11061-015-9441-9.

Francesca Gambino

francesca.gambino@libero.it; francesca.gambino@unipd.it

1 Università degli Studi di Padova, Palazzo Maldura, Piazzetta Gianfranco Folena 1, 35137 Padua, Italy 